Article

\title{
Exogenously Applied Nitric Oxide Enhances Salt Tolerance in Rice (Oryza sativa L.) at Seedling Stage
}

\author{
Teferi Alem Adamu ${ }^{1}\left(\mathbb{0}\right.$, Bong-Gyu Mun ${ }^{1}$, Sang-Uk Lee ${ }^{1}$, Adil Hussain ${ }^{1,2}$ and \\ Byung-Wook Yun ${ }^{1, *}$ \\ 1 School of Applied Bioscience, College of Agriculture and Life Science, Kyungpook National University, \\ 80 Daehak-ro, Bukgu, Daegu 41566, Korea; teferialem@gmail.com (T.A.A.); mun0301@naver.com (B.-G.M.); \\ uk0gam@gmail.com (S.-U.L.); adilhussain@awkum.edu.pk (A.H.) \\ 2 Department of Agriculture, Abdul Wali Khan University, Mardan 23200, Pakistan \\ * Correspondence: bwyun@knu.ac.kr; Tel.: +82-(0)53-950-5712
}

Received: 18 October 2018; Accepted: 22 November 2018; Published: 23 November 2018

\begin{abstract}
Salinity is one of the major abiotic factors that limit rice production worldwide. Previous trends show that salt concentration in rivers is increasing consistently, posing potentially adverse threats in the near future. Thus, crops currently being cultivated, particularly in small-scale farming systems, are under high threat from salinity. In this study, we investigated the mitigating effect of nitric oxide (NO) on salt stress in rice based on the assessment of changes in the transcript levels of different genes and the phenotypic response of rice genotypes. We observed that exogenously applied NO increased the expression levels of OsHIPP38, OsGR1, and OsP5CS2 in the susceptible genotype of rice, whereas in the tolerant genotype, the effect of $\mathrm{NO}$ was mainly in counteracting the salt-induced gene expression that diverts cellular energy for defense. Moreover, seedlings that were pretreated with NO showed high biomass production under salt stress conditions, indicating the positive role of $\mathrm{NO}$ against salt-induced leaf chlorosis and early senescence. The effect of NO-mediated enhancement was more pronounced in the salt tolerant genotype. Therefore, the use of NO with the integration of tolerant genes or genotypes will enhance salt tolerance levels in rice.
\end{abstract}

Keywords: NO-induced salt tolerance; salinity mitigation; stress-related genes

\section{Introduction}

Rice is a major cereal crop grown globally and is of principal importance as a staple food source for more than half of the world population [1]. World rice production is projected to be 915 million tons by 2050, which is far less than that expected based on the yield doubling hypothesis to supply for the global food demand [2,3]. The current trend also shows that no significant increase in annual production is observed in the major rice growing regions [4,5]. The major factors that influence rice production and do not allow it to keep pace with the global population growth are associated with biotic [6] and abiotic factors [7] that are aggravated by climate change [8-10].

Salinity is one of the major abiotic factors that limit crop production in many parts of the world. About $20 \%$ of the cultivated and $50 \%$ of the irrigated land is affected by high salinity levels [11]. In Asia alone, where more than $90 \%$ of the world's rice production is harvested, 21.5 million ha of agricultural land is affected by salt stress [12]. For this reason, the large area of irrigated lands became fallow. Moreover, even the level of salt in the river water has increased at various times and has the potential to render additional farmlands uncultivable [13]. High salinity affects plant growth and development through physiological water stress conditions, ion toxicity [14] and accumulation of reactive oxygen species (ROS) that cause protein denaturation, lipid peroxidation, DNA damage, and inhibition of enzymes $[15,16]$. Rice, a glycophytic plant by nature, is sensitive to salt stress and has a threshold level 
of $3 \mathrm{dSm}^{-1}$ [17]. Salinity causes yield loss in rice by more than $50 \%$ [18] and for every $1 \mathrm{dSm}^{-1}$ increase in salinity above the threshold level, there is a $12 \%$ reduction [17] depending on the growth stage in which the pant is exposed to salinity. The physiological mechanism of salt tolerance is generally based on $\mathrm{Na}^{+}$exclusion, osmotic stress adjustment and ROS detoxification or scavenging system [19-21].

The cellular accumulation of proline is one of the mechanisms of mitigation of salt stress through which plants counteract the effects of osmotic stress and maintain cellular homeostasis [22-24]. Higher salt-induced production and accumulation of proline were observed in tolerant than in the susceptible genotypes of rice [25,26] and wheat [27]. The biosynthesis of proline is encoded by 1-pyrroline-5-carboxylate synthetase (P5CS) gene which consists of two isoforms, OsP5CS1 (LOC_Os01g62900) and OsP5CS2 (LOC_Os05g38150) [28].

The sequential break down of oxidative molecules by antioxidant enzymes-such as superoxide dismutase (SOD), ascorbate peroxidase (APX), catalase (CAT), peroxidase (POD), and glutathione reductase (GR) - is another mechanism of salt tolerance in different genotypes [29-31]. GR plays a significant role in the major ROS scavenging pathways of ascorbate-glutathione and glutathione peroxidase (GPX) cycles [32,33]. Different studies on the response of contrasting rice genotypes to salinity by Hossain, et al. [34] and cold stress by Huang and Guo [35] showed that the activity of SOD, CAT, GR, and APX enzymes were increased in tolerant line compared to susceptible genotypes. The other important proteins that are involved in transcriptional response to abiotic stress (cold and drought) in rice are heavy metal-associated isoprenylated plant proteins (HIPPs) [36]. HIPPs are metallochaperones that contain one or two conserved domains: heavy metal association domains with two cysteine residues and a heavy metal-associated isoprenylated motif at the C-terminus [37]. However, the transcriptional response of HIPP gene family for salt stress has not been addressed in previous studies. In this study, one of the rice HIPPs, OsHIPP38, was studied for its transcriptional response to salinity in contrasting genotypes. OsHIPP38 is one of the candidate genes located in the salt tolerant quantitative trait locus (Saltol region) on chromosome 1.

Nitric oxide (NO), a gaseous redox-active molecule, plays an important role in the regulation of plant growth and development and is involved in the defense strategy of plants against biotic and abiotic stresses [38,39]. NO is involved in the scavenging of superoxide radical by activating antioxidative enzymes, such as SOD, CAT, APX, and POD [40]. NO also directly interacts with superoxide radicals when the latter is produced in excess due to severe stress conditions and their reaction generates peroxynitrite $\left(\mathrm{ONOO}^{-}\right)$[41] which is again involved in the scavenging of hydrogen peroxide [42]. NO induced antioxidative enzyme (SOD, GR, APX, and CAT) activities were increased in rice and wheat under cadmium stress $[43,44]$. Similar findings also showed antioxidative role of NO on drought stress in rice [45], on salt in wheat, chickpea, and soybean [46-48] and on cold stress in wheat and cucumber seedlings $[49,50]$. The other ameliorating effect of NO on abiotic stress is through the metabolism and production of osmolytes in plants [51]. NO triggered biosynthesis and accumulation of proline content was reported in wheat, cucumber, and Chinese cabbage against salt stress [52-54]. Therefore, considering the multifaceted role of NO under stress conditions in different species, this study was designed to evaluate the mitigation effect of $\mathrm{NO}$ on salt stress in susceptible and tolerant rice genotypes with regard to gene modulations and phenotypic response. In addition, the transcriptional response of OsHIPP38 (LOC_Os01g20830) to salinity was studied in contrasting genotypes.

\section{Materials and Methods}

\subsection{Plant Materials}

Three rice genotypes, HP3319-2wx-6-3-1-B (HP), FL478 (known tolerant check, developed by IRRI), and Ediget (susceptible), were included in the experiments. However, based on our varietal screening data for salt stress, HP was found to be more tolerant than the standard tolerant line, FL478. Thus, HP was used as a tolerant check in the NO experiments. The experiments were done in two sets for the gene expression analysis and for determining NO-induced phenotypic response to salinity. 
A completely randomized design (CRD) with three and four replications was used for molecular and phenotypic experiments, respectively. The total number of treatments were four (Control, $\mathrm{SNP}, \mathrm{NaCl}$, and $\mathrm{SNP}+\mathrm{NaCl})$.

\subsection{Growth Conditions}

\subsubsection{Gene Expression Experiment}

Rice seeds were surface sterilized with Sportak fungicide (FMC Australia, Sydney, NSW, Australia) solution, used at a rate of $50 \mu \mathrm{L}$ per $100 \mathrm{~mL}$ of water for $24 \mathrm{~h}$ at $30^{\circ} \mathrm{C}$. After removing the solution, seeds were rinsed three times with distilled water and sown on square petri dish. Seedlings were grown in the growth room under a $16 / 8 \mathrm{~h} \mathrm{light/dark} \mathrm{cycle} \mathrm{at} \mathrm{a} \mathrm{constant} \mathrm{temperature} \mathrm{of} 23^{\circ} \mathrm{C}$. Two-week-old rice seedlings were pretreated with sodium nitroprusside (SNP, NO donor) for $24 \mathrm{~h}$ at a concentration of $0.25 \mathrm{mmol} / \mathrm{L}$. Thereafter, the solution was removed and Petri dishes were flooded with distilled water two times to avoid any further effect of SNP. After three days, salt stress $(150 \mathrm{mmol} / \mathrm{L} \mathrm{NaCl})$ was imposed.

\subsubsection{Phenotypic Experiment}

Pre-germinated seeds were sown on styrofoam, floating in a small box containing distilled water, as described by Glenn and Senadhira [55]. After two days, the water was replaced with half-strength hoagland solution (KisanBio, Seoul, Korea), which was changed again to a full dose after three days. The seedlings were grown in a growth chamber at $28 / 22{ }^{\circ} \mathrm{C}$ day/night temperature and $14 \mathrm{~h} \mathrm{light}$ conditions, i.e., under simulated field conditions. The light intensity was $450 \mu \mathrm{mol} \mathrm{m}^{-2} \mathrm{~s}^{-1}$ with a relative humidity of $70 \%$. The solution used during seedling growth was changed every three or four days and the $\mathrm{pH}$ was maintained at 5 by adjusting with $\mathrm{NaOH}$ or $\mathrm{HCl}$. Two-week-old seedlings were then pretreated with SNP as described above and after three days, salt stress $(100 \mathrm{mmol} / \mathrm{L} \mathrm{NaCl})$ was imposed. The roots were separated from the shoots by cutting on the collar points, 10 days after salt induction. The dry biomass data were collected after drying the samples at $70{ }^{\circ} \mathrm{C}$ for $72 \mathrm{~h}$. Four representative plants were considered for each genotype in each replication. The data collected from four individual plants were used to generate mean value that was used for analysis of variance (ANOVA).

The level of salinity was optimized to $100 \mathrm{mmol} / \mathrm{L} \mathrm{NaCl}$ solution based on the response of selected rice genotypes in our observation in which 60 and $120 \mathrm{mmol} / \mathrm{L}$ salt concentrations were used for stress induction. The result showed that genotypes were not affected by $60 \mathrm{mmol} / \mathrm{L}$ salinity. Whereas salinity at $120 \mathrm{mmol} / \mathrm{L}$ was detrimental to all genotypes (Figure S1). The concentration and method of application of SNP were also formulated after our observations. The results showed that application of NO together with salt stress was not found important to seedlings and because of this, pretreatment application was used (Figure S2 and S3).

\subsection{Quantitative Real Time PCR ( $q P C R$ ) Analysis}

For qPCR analysis, leaf samples were collected from each replication at 0, 6, 12, 24, and $48 \mathrm{~h}$ after exposure to salinity and were immediately frozen in liquid nitrogen. Total RNA was extracted using Trizol isolation method (Molecular Research Center Inc., Cincinnati, OH, USA). About $1 \mu \mathrm{g}$ of total RNA was used for cDNA synthesis using reverse transcript (RT) kit (BIOFACT Co., Ltd., Daejeon, $\mathrm{CR}$, Korea). The concentration of cDNA was diluted to $200 \mathrm{ng} / \mu \mathrm{L}$ with nuclease free water. $20 \mu \mathrm{L}$ qPCR mix was prepared including $1 \mu \mathrm{L}$ template using $2 x$ real-time PCR master mix (BIOFACT Co., Ltd., Daejeon, Korea). The qPCR analysis was carried out for 40 cycles with an Eco real-time PCR system (Illumina Inc., Hayward, CA, USA). The amount of transcript was quantified using OsUBQ1 as internal standard for normalization. The primers used for qPCR analysis are presented in Table 1. 
Table 1. Sequences of primers used in qPCR analysis.

\begin{tabular}{cllcc}
\hline No & Gene & \multicolumn{1}{c}{ F-Primer } & R-Primer & Size \\
\hline 1 & OsHIPP38 & TCTCGGAGTACGGCTACGTC & GGTGCATGCATTAGGGTTCT & 158 \\
2 & OsGR1 & GGCAGGCAGTTTGGTTGATG & GTTGAGCTCGGCTACCAGTT & 110 \\
3 & OsP5CS2 & TAGCAGGACTGTTGGCACTG & CCGCTATTTGAAGCCAAGAC & 223 \\
4 & OsUBQ1 & GACGGACGCACCCTGGCTGA & TGCTGCCAATTACCATATACC & 396 \\
\hline
\end{tabular}

\subsection{Total Protein and Antioxidant Enzyme Assay}

For determination of antioxidant activity and total protein content, $100 \mathrm{mg}$ leaf samples were ground separately by freezing with liquid nitrogen. Then, each sample was immediately homogenized with $1 \mathrm{~mL}$ of $50 \mathrm{mmol} / \mathrm{L}$ phosphate buffer ( $\mathrm{pH}$ 7.5). After $10 \mathrm{~min}$ incubation on ice, the homogenate was centrifuged at $12,000 \mathrm{rpm}$ for $10 \mathrm{~min}$ at $4{ }^{\circ} \mathrm{C}$. The supernatant was transferred to a fresh tube and used as a crude source for estimation of enzymatic activities. Total protein content was quantified using the Bradford assay [56]. The CAT activity was estimated according to Aebi [57] by adding $50 \mu \mathrm{L}$ $\mathrm{H}_{2} \mathrm{O}_{2}(0.2 \mathrm{~mol} / \mathrm{L}$ to $50 \mu \mathrm{L}$ crude supernatant. The absorbance was read at a wavelength of $240 \mathrm{~nm}$. For POD estimation, $50 \mu \mathrm{L}$ supernatant, $50 \mu \mathrm{L}$ pyrogallol, $25 \mu \mathrm{L} \mathrm{H}_{2} \mathrm{O}_{2}$, and $100 \mu \mathrm{L}$ phosphate buffer were added sequentially and the mixture was incubated for $5 \mathrm{~min}$ at room temperature under dark conditions. Subsequently, $\mathrm{H}_{2} \mathrm{SO}_{4}(5 \%)$ was added to the mixture and absorbance was read at $420 \mathrm{~nm}$.

\subsection{Statistical Analysis}

One-way ANOVA was carried out using GraphPad software version 7.00 (GraphPad Software, San Diego, CA, USA) and for mean separation, Tukey's multiple comparison test was used. $p \leq 0.05$ was considered as a significant value for mean differences. Each mean value was presented as mean \pm standard error (SE).

\section{Results}

\subsection{Salt Induced Change in the Expression of OsHIPP38 in Contrasting Genotypes}

OsHIPP38 was selected because of its locus in the salt tolerant QTL on chromosome 1. The expression analysis was done using leaf samples collected at $0,6,24$, and $48 \mathrm{~h}$ from susceptible (Ediget) and tolerant rice genotypes (HP and FL478) treated with salt $(150 \mathrm{mmol} / \mathrm{L} \mathrm{NaCl})$. The results showed that the transcript accumulations and expression patterns of OsHIPP38 were different over time in all genotypes (Figure 1). In Ediget, the level of expression showed significant difference between the control and treated seedlings. OsHIPP38 was downregulated after $48 \mathrm{~h}$ of salt stress in susceptible genotype (Figure 1A). In contrast, significantly high expression was observed in the two tolerant genotypes but the time of maximum expression, regardless of the amount, was different in both genotypes (Figure 1B,C). In HP, the expression was optimum at $24 \mathrm{~h}$, whereas in FL478, the expression reached on its peak immediately after $6 \mathrm{~h}$ and then dropped to the level of the control after $48 \mathrm{~h}$. The maximum expression levels in HP and FL478 were more than 4- and 10-times of their respective control treatments. 


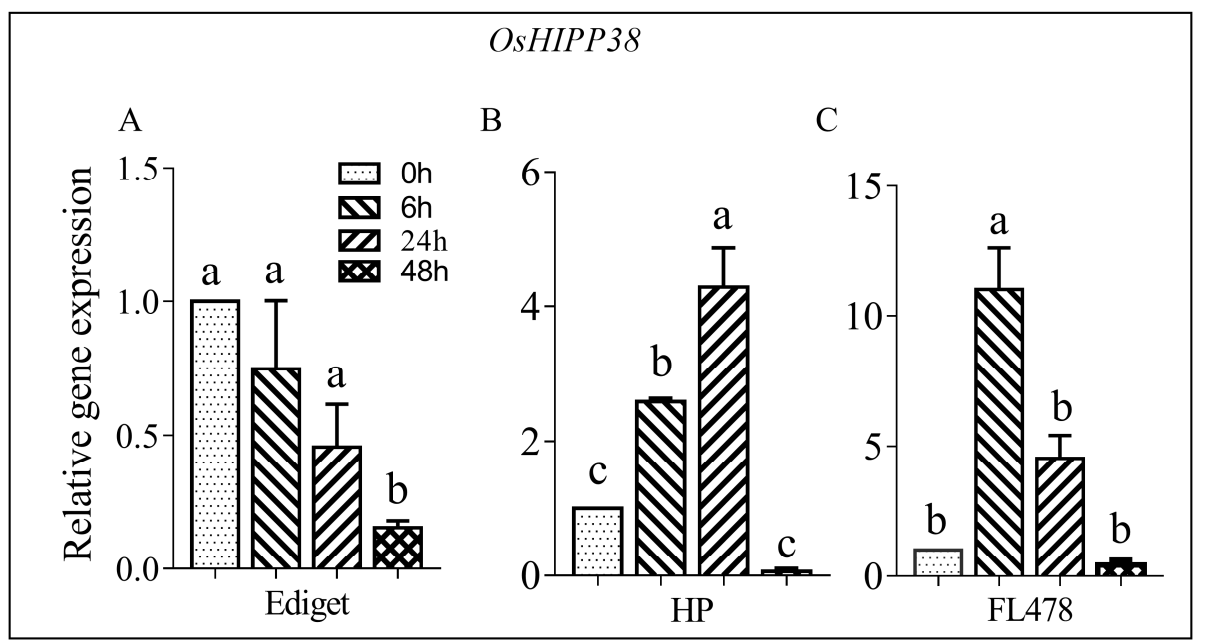

Figure 1. Expression analysis of OsHIPP38 gene in contrasting rice genotypes under salt stress. Two-week-old rice seedlings were treated with $\mathrm{NaCl}(150 \mathrm{mmol} / \mathrm{L})$ and samples were collected at different time points from 0 to $48 \mathrm{~h}$. (A) susceptible genotype; (B,C) tolerant genotypes. Relative gene expression-the level of gene expression in relative to the internal control. For the expression analysis, $O s U B Q 1$ was used as the internal control. Means followed by the same letter are not significantly different according to Tukey's significance test at $p<0.05$.

\subsection{NO Induced Response of OsHIPP38, OsGR1, and OsP5CS2 to Salinity in Rice}

The results of NO triggered responses of OsHIPP38 and other genes are summarized in Figure 2. In the previous section, the relative expression of OsHIPP38 was downregulated in susceptible genotype. However, pretreatment of seedlings with SNP $(0.25 \mathrm{mmol} / \mathrm{L})$ for $24 \mathrm{~h}$ triggered more than 6 and 2.5-times changes in expression before and after salt induction, respectively (Figure 2D). Significant differences were observed in the transcript levels among the samples collected from three groups of seedlings (Figure 2A-C). The highest expression was observed for NO-pretreated seedlings before and after salt induction ( 0 and $12 \mathrm{~h}$ ). However, after $24 \mathrm{~h}$ of salt imposition, the transcript accumulation was the same in all samples. Gene expression was also analyzed for OsGR1 and OsP5CS2 in the same genotype under same conditions. Before salt stress, the relative expressions for both genes were the same in between control and NO pretreated seedlings. However, after $12 \mathrm{~h}$ of salt exposure, NO pretreatment induced significant amount of transcript accumulation for both genes in the susceptible genotype. NO increased the relative expression level consistently at 12 and $24 \mathrm{~h}$ for OsGR1. NO also induced optimum expression level for OsP5CS2 at $12 \mathrm{~h}$. However, neither salt nor the interaction effect of $\mathrm{NO}$ and salt induced changes after 12 (Figure 2E,F).

In tolerant genotype (HP), the relative expression of the three genes were the same in control and NO-pretreated seedlings before salt application. NO pretreatment did not also induce any significant changes in the expression of OsHIPP38 and OsGR1 genes after the imposition of salt stress (Figure 2G,H). However, salinity increased expression of OsHIPP38 and OsGR1 in non-pretreated seedlings after $12 \mathrm{~h}$. The relative expression of OsP5CS2 in NO pretreated and no-treated seedlings was increased after 12 and $24 \mathrm{~h}$ of salt stress compared to control treatments, respectively (Figure 2I). 


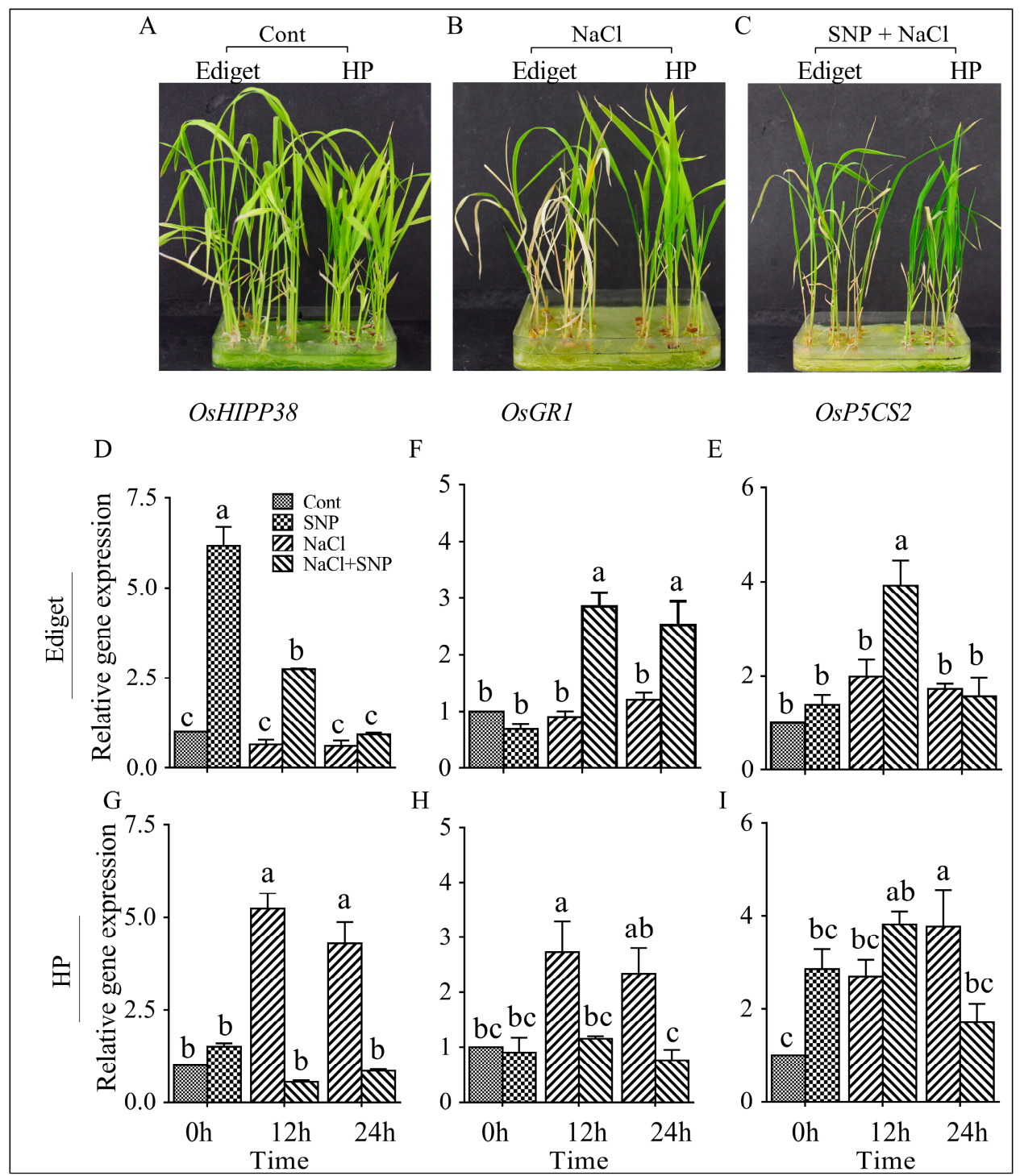

Figure 2. Nitric oxide enhanced OsHIPP38, OsGR1, and OsP5CS2 expression in rice under salinity. OsUBQ1 was used as the internal control for expression analysis. Relative gene expression-the level of gene expression in relative to the internal control. Two-week-old seedlings were treated with SNP $(0.25 \mathrm{mmol} / \mathrm{L})$ for $24 \mathrm{~h}$ and $\mathrm{NaCl}(150 \mathrm{mmol} / \mathrm{L})$ was applied after three days. Cont-control (A), $\mathrm{SNP}$ - samples collected after SNP treatment but before salinity, $\mathrm{NaCl}$ - salt treated (B), $\mathrm{SNP}+\mathrm{NaCl}$ SNP-treated seedlings exposed to $\mathrm{NaCl}(\mathrm{C})$ : ( $\mathrm{NaCl}$ — sodium chloride and $\mathrm{SNP}$-sodium nitroprusside). $(\mathbf{D}, \mathbf{E}, \mathbf{F})$ relative gene expression for OsHIPP38, OsGR1, and OsP5CS2 in Ediget (susceptible genotype) and $(\mathbf{G}, \mathbf{H}, \mathbf{I})$ in HP (tolerant genotype). The data are presented as means $\pm \mathrm{SE}(n=3)$ and data followed by the same letter are not significantly different according to Tukey's significance test at $p<0.05$.

\subsection{Effects of NO on Protein and Enzyme Activity in Rice Genotypes Exposed to Salinity}

Significant differences were observed in total protein content and the activity of POD and CAT enzymes between treated and control samples in the susceptible genotype (Figure 3A-C). Salinity affected the total protein content and POD but not the CAT activity. The pretreatment of seedlings with NO increased the protein content and activity of CAT. However, no significant difference was observed between salt stressed $(\mathrm{NaCl})$ and $\mathrm{NO}$ pretreated $(\mathrm{SNP}+\mathrm{NaCl})$ seedlings for the POD activity. In the tolerant genotype, salinity did not affect total protein content and enzyme activities. However, NO pretreatment induced changes by increasing significantly the total protein content and the activities of both enzymes in tolerant genotype (Figure 3D-F). 


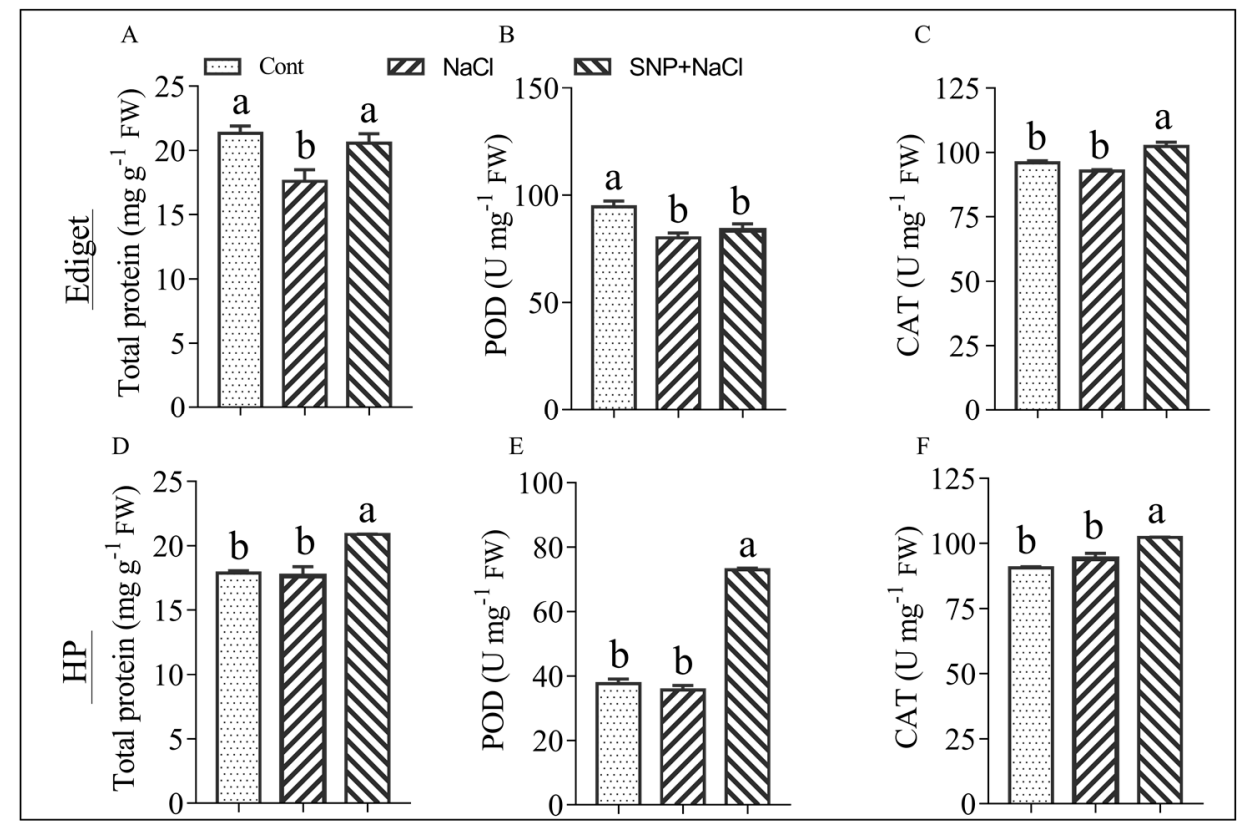

Figure 3. Effects of nitric oxide (NO) on the total protein content and activities of antioxidant enzymes in rice seedlings exposed to salinity. Two-week-old seedlings were treated with sodium nitroprusside (SNP; $0.25 \mathrm{mmol} / \mathrm{L})$ for $24 \mathrm{~h}$, and $\mathrm{NaCl}(150 \mathrm{mmol} / \mathrm{L})$ was applied after three days. Leaf samples were collected after $24 \mathrm{~h}$ of salt treatment. Cont-Control, $\mathrm{NaCl}$-sodium chloride (salt stress), and SNP $+\mathrm{NaCl}-\mathrm{SNP}$ pretreated seedlings exposed to salt stress. (A,D) total protein, (B,E) POD-peroxidase activity and (C,F) CAT—catalase activity, Ediget-susceptible genotype, $\mathrm{HP}$ - tolerant genotype, $\mathrm{U}$ - enzyme unit, and $\mathrm{mg} \mathrm{g}^{-1} \mathrm{FW}$-milligram per gram of fresh weight. The data are presented as means $\pm \mathrm{SE}(n=3)$ and data followed by the same letter are not significantly different according to Tukey's significance test at $p<0.05$.

\subsection{Effect of NO on Phenotypic Traits of Rice Genotypes under Salinity}

An experiment was conducted to study the phenotypic effect of NO pretreatment on salt $(100 \mathrm{mmol} / \mathrm{L} \mathrm{NaCl})$ tolerance in rice seedlings under $28 / 22^{\circ} \mathrm{C}$ day $/$ night temperature. The results showing the negative effect of salinity on rice seedlings and NO induced response of genotypes including the statistical analysis are presented in Figure 4.

ANOVA showed that there were significant differences for the root length and dry biomass traits in both genotypes. In the susceptible genotype, variation was not observed in between control and $\mathrm{NO}$ pretreated seedlings for root length. Salinity $(\mathrm{NaCl})$ affected the root growth significantly. Pretreatment of seedlings with NO did not show any change on salt induced negative effect in root length (Figure 4A). Like root length, salinity caused a significant decrease in root and shoot dry biomass (Figure 4B-D). NO pretreatment showed improvement and negative effect in shoot and root dry biomass respectively, though it was not significant. A significant difference was observed between control and NO pretreated seedlings for root and shoot dry biomasses when there was no salt stress, indicating the positive role of NO for plant growth and development.

In the tolerant genotype, significant differences were also observed for root, shoot, and total dry biomasses (Figure 4G-I). Salinity affected root length significantly in tolerant genotype. However, the negative effect of salt on root growth was improved by NO application (Figure $4 \mathrm{~F}$ ). Salinity also affected dry biomass significantly. However, like root length, NO also reversed the salt induced reduction in dry biomass to the control level (Figure 4G-I). In no stress condition, the application of NO in tolerant genotype showed negative effect on root length compared to the control treatment. However, its application did not induce any significant changes on root and shoot dry biomasses. 


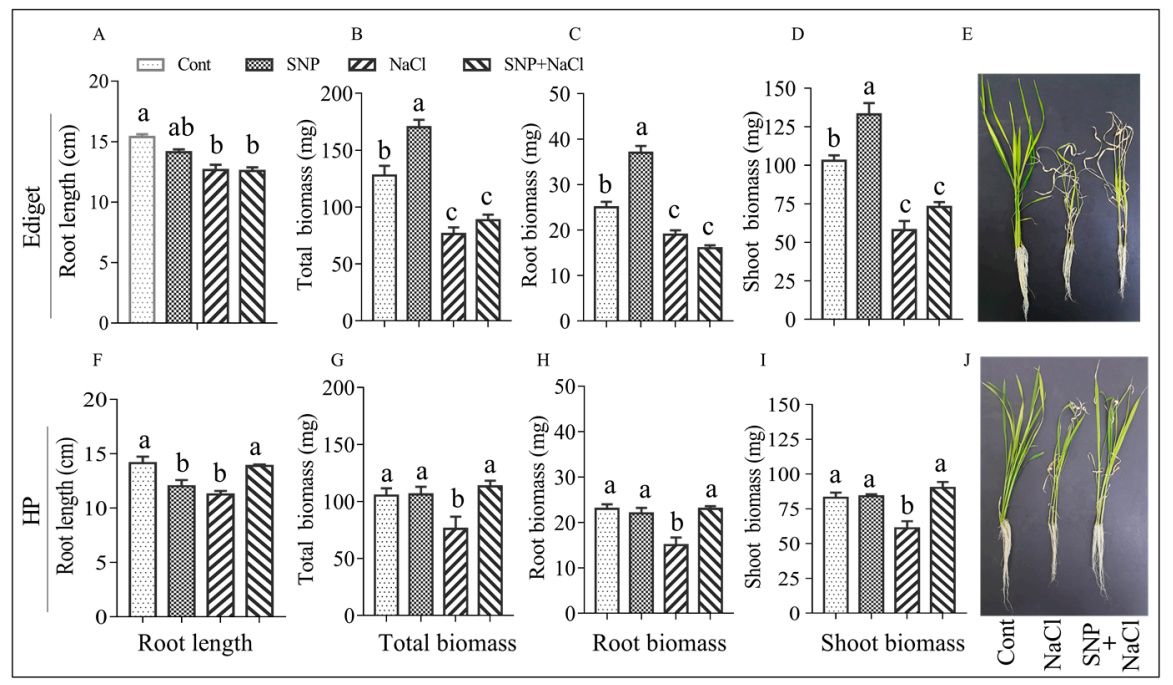

Figure 4. NO enhanced root length and dry biomass of rice seedlings exposed to salinity. Seedlings were grown in a growth chamber under $28 / 22{ }^{\circ} \mathrm{C}$ day/night temperatures. Two-week-old seedlings were then treated with sodium nitroprusside (SNP; $0.25 \mathrm{mmol} / \mathrm{L})$ for $24 \mathrm{~h}$, and $\mathrm{NaCl}(100 \mathrm{mmol} / \mathrm{L})$ was applied after three days. Data were collected after 10 days of salt stress. Cont—control, SNP-SNP treatment for $24 \mathrm{~h}$ ( $\mathrm{NO}$ as a sole treatment), $\mathrm{NaCl}$ - salt stress, and $\mathrm{SNP}+\mathrm{NaCl}$ - seedlings treated with SNP and then exposed to salt. Ediget-susceptible genotype, HP-tolerant genotype, $\mathrm{cm}$ - centimeter and, mg-milligram. The data are presented as means $\pm \mathrm{SE}(n=4)$ and means with the same letters are not significantly different according to Tukey's significance test at $p<0.05$.

The percent reduction or gain in seedling dry biomass because of salinity and NO pretreatment was determined as

$$
\text { Reduction }(\%)=\frac{\text { control }- \text { treated }}{\text { control }} \times 100
$$

Salt-treated seedlings showed $32 \%$ and $27 \%$ reduction in the root and shoot dry biomass, respectively, in the tolerant genotype (HP). Whereas, NO-pretreatment showed a gain of $3 \%$ and $9 \%$ in the root and shoot biomass, respectively over the corresponding values in non-treated seedlings under salt stress condition (Table 2). NO also decreased salt induced effect on shoot biomass by $14 \%$ in susceptible genotype (Ediget). On the other hand, NO pretreatment aggravated the effect of salinity on root biomass in Ediget by increasing the percent reduction from $26 \%(\mathrm{NaCl})$ to $38 \%(\mathrm{SNP}+\mathrm{NaCl})$.

Table 2. Effect of nitric oxide (NO) on salt-induced reduction in the biomass of rice genotypes.

\begin{tabular}{ccccccc}
\hline \multirow{2}{*}{ Genotype } & \multirow{2}{*}{ Trait } & \multicolumn{3}{c}{ Dry Biomass (mg) } & \multicolumn{2}{c}{ Reduction (\%) ${ }^{\dagger}$} \\
\cline { 3 - 7 } & & Control & NaCl & SNP+NaCl & NaCl & SNP+NaCl \\
\hline HP & \multirow{2}{*}{ Root } & 22.50 & 15.25 & 23.25 & 32.22 & -3.33 \\
Ediget & 25.00 & 18.50 & 15.50 & 26.00 & 38.00 \\
\hline HP & \multirow{2}{*}{ Shoot } & 82.75 & 60.75 & 90.00 & 26.59 & -8.76 \\
Ediget & & 102.75 & 58.25 & 73.00 & 43.31 & 28.95 \\
\hline
\end{tabular}

+ Minus sign (-) indicates percent weight gain over the control. $\mathrm{NaCl}-$ sodium chloride $(100 \mathrm{mmol} / \mathrm{L})$ for 10 days, SNP-sodium nitroprusside $(0.25 \mathrm{mmol} / \mathrm{L})$ for $24 \mathrm{~h}$. SNP+NaCl: seedlings were treated with SNP for $24 \mathrm{~h}$ and then exposed to salinity after three days. The root and shoot dry weight data were collected from the salt-stressed seedlings (after 10 days of stress and drying for $72 \mathrm{~h}$ at $70{ }^{\circ} \mathrm{C}$.

\section{Discussion}

\subsection{OsHIPP38 Shows Differential Response to Salinity in Contrasting Genotypes}

HIPPs have been known to have significant role in abiotic stress responses in different plant species. In Arabidopsis, a number of AtHIPPs genes are involved in the transcriptional responses 
to biotic and abiotic stresses [37,58]. Similarly, in rice, about 55 genes encode HIPPs. Members of this gene family are involved in regulation of stress responses in rice. For example, OsHIPP41 showed transcriptional responses to cold and drought stresses. OsHIPP09 and OsHIPP15 also showed downregulated expression in response to salinity in rice [36]. OsHIPP38 is the rice HIPP coding gene that is located in salt tolerant QTL region on chromosome 1. Therefore, we sought to study the transcriptional response of OsHIPP38 to salinity using different rice genotypes. Modulation of gene expression is one of the most significant molecular mechanisms of abiotic stress response in plants. In present study, the expression pattern and relative expression of OsHIPP38 were different in the contrasting rice genotypes under salt stress. The transcript accumulation of OsHIPP38 was high in tolerant while low in susceptible genotype compared to control seedlings (Figure 1), suggesting transcriptional responses of OsHIPP38 to salinity in rice.

Moreover, a functional protein association analysis of OsHIPP38 also showed its co-expression with OsJ_03346 (heat shock protein DnaJ), core histone H2A/H2B/H3/H4 protein and MYB family transcription factors, which are involved in biotic and abiotic stress tolerance [59]. The OsJ_03346 protein plays an important role in protein folding and disaggregation that aids in cell survival under unfavorable conditions. It also assists in the function of the kilodalton heat shock protein 70 (HSP70) family, which encodes a group of highly conserved chaperone proteins that play protective roles against heat and other environmental stresses [60]. Therefore, functional protein association with the known genes also reveals the transcriptional response of OsHIPP38 gene to abiotic stress in rice. However, showing transcriptional response does not necessarily mean that this gene is involved in salt tolerance. Therefore, functional analysis studies are required to confirm the role of OSHIPP38 in rice salt tolerance.

\subsection{NO Enhances the Expression level of OsHIPP38, OsGR1 and OsP5CS2 in Susceptible Genotype under Salinity}

The transcript accumulation of OsHIPP38 was increased in NO-pretreated seedlings compared to control seedlings before the application of salt stress, indicates the responsiveness of OsHIPP38 to NO. Our transcription data in rice also showed that some members of the OsHIPP gene family were upregulated in response to CysNO (NO-donor) [61]. Under salt condition, NO-pretreatment also showed increased OsHIPP38 expression level compared to non-treated seedlings. Thus, NO-induced gene modulation in the susceptible genotype suggests the enhancing role of $\mathrm{NO}$ for the transcriptional response of OsHIPP38 gene to salinity.

The relative expression level of OsGR1 was not increased significantly under salt stress in the susceptible genotype. However, NO pretreatment increased expression, indicating the role of NO in enhancing antioxidant enzymes in susceptible genotype. A lower enzyme activity of GR was also reported by [34] in susceptible line compared to the tolerant genotype in salt stressed rice seedlings. In a similar study on mustard, GR activity was low in susceptible line compared to the tolerant genotype [62]. GR is a key enzyme in the ascorbate-glutathione cycle that is modulated by NO and NO-based post-translational modifications under abiotic stresses [39,63]. Therefore, one of the roles of NO in salt stress mitigation is enhanced expression of antioxidant enzymes that scavenge excess reactive oxygen species $\left(\mathrm{H}_{2} \mathrm{O}_{2}\right)$.

The increased transcript level of the proline biosynthesis gene (OsP5CS2) in NO-pretreated seedlings of the susceptible genotype under saline conditions, indicates the role of $\mathrm{NO}$ in the production of proline, which plays a significant role in counteracting salt-induced osmotic stress [64]. NO-induced proline accumulation in response to salinity in other crop species-such as wheat [53], cabbage [52], chickpea [46], and cucumber [54]—are in agreement with the present study.

\subsection{NO Counteracts Salt-Induced Gene Expression in the Tolerant Genotype in Salt Stress Conditions}

$\mathrm{NO}$ is involved in the scavenging of ROS by activating antioxidative enzymes when plants exposed to abiotic stress [40]. However, in the present study, NO pretreatment decreased the expression 
levels of OsHIPP38, OsGR1, and OsP5CS2 genes compared to non-treated seedlings in tolerant genotype under saline condition. Such counteracting effect of NO on stress induced gene expression was also reported in rice exposed to copper [65] and cadmium [66]. Low accumulation of hydrogen peroxide $\left(\mathrm{H}_{2} \mathrm{O}_{2}\right.$, a substrate for GR) might be the possible reason for decreased OsGR1 expression in NO-pretreated seedlings compared to non-treated ones under saline condition. Because, NO interacts with superoxide radical $\left(\mathrm{O}_{2}{ }^{-}\right.$, a precursor for $\left.\mathrm{H}_{2} \mathrm{O}_{2}\right)$ and produces peroxynitrite $\left(\mathrm{ONOO}^{-}\right)$[41] . NO-triggered decrease in gene expression may implicate less energy dissipation for transcriptional activity in the tolerant genotype. In stress conditions, resources are mobilized from the growth-related biosynthetic active sites to metabolic reactions that aid in defense strategies [67].

\subsection{NO Enhances Protein Content and Enzymatic Activities in the Contrasting Genotypes}

Under stress conditions, plants strive to break down toxic molecules like ROS through the production of antioxidative enzymes and osmolytes. However, the biosynthesis and sufficiently accumulation of these stress alleviating enzymes and osmoprotectants are different within and between species depending on their tolerant ability $[31,68]$. In this study, the total protein content and POD activity were significantly decreased in susceptible genotype, indicates our work is in agreement with the studies. The studies reported by Kibria, et al. [69] and by [34] also showed that salinity affected the activity of CAT which was not influenced in this work. Whereas increased activity of CAT in susceptible rice genotypes was observed in another study [70]. Thus, it might be possible to suggest that the activity of CAT is controversial in susceptible genotype under saline condition. However, salt induced reduction in protein content was compromised by the application of $\mathrm{NO}$ to the level of control treatment. The application of NO pretreatment in rice seedlings also improved the activity of CAT under saline condition. Whereas NO induced enhancement was not observed in POD activity. CAT and POD are involved in the scavenging of $\mathrm{H}_{2} \mathrm{O}_{2}$ in common. Therefore, CAT might have fast reaction ability than POD. In cadmium and zinc induced stress on pigeon pea, the capacity of CAT in ROS scavenging activity was greater than POD [71]. Moreover, POD is also involved in other plant physiological processes such as development, cell wall crosstalk, and lignification [72,73].

In the tolerant genotype, total protein content, CAT, and POD activities were not affected by salinity. This might be because of the lower rate of ROS production and accumulation in tolerant genotype at early time point of stress. The past study also showed that the amount of ROS was increased earlier in susceptible genotype than tolerant genotype [31]. Unchanged POD and CAT activities were also reported in tolerant rice genotype exposed to cold stress [35]. However, the result obtained in the present study was in contradiction with another study in which POD activity showed increasing by more than $90 \%$ of its activity in NO non-treated seedlings under salinity [31]. NO application induced a significant increase in total protein and in the activity of both enzymes. NO induced increase was larger in POD activity ( $>100 \%$ of its activity in control) than the increase in CAT activity and total protein content.

\subsection{NO Maintains the Production of Biomass in Salt-Stressed Seedlings}

Salinity significantly affected the root length and biomass in both contrasting genotypes although the degree of reduction for both traits was different in each genotype. The large reduction in biomass is associated with poor carbohydrate metabolism that leads to low starch accumulation [74]. Such phenomenon is usually observed in salt-susceptible genotypes in which the chlorophyll content is largely decreased in response to osmotic and toxic effects of salt [74-76]. Salinity also induces a large amount of ROS formation [77] that causes disruption of cellular homeostasis and oxidative burst in plant cells [31,78]. Because of this, susceptible genotypes show chlorosis and leaf senescence that leads to poor growth within a few days of exposure to salinity. In the present study, significant reduction in dry biomass was observed. However, the salt-induced biomass reduction was reversed by the application of NO. In a similar study on soybean, large dry biomass was observed in NO treated plants under saline condition [47]. The role of $\mathrm{NO}$ on biomass maintenance was also reported in wheat 
under salt stress [44]. In addition to its role in ROS scavenging, NO is involved in repairing of salt induced damage on chloroplast that decreases carbohydrate synthesis $[79,80]$. NO also enhances the assimilation and transportation of nitrogen in low nutrition condition and maintains the leaf nitrogen content [81]. For these and other physiological roles of NO [82], seedlings were able to stay green and maintain biomass production under stress conditions. However, NO pretreatment showed negative effect on root biomass and increased salt induced reduction by $12 \%$ in the susceptible genotype. This might be because of the high amount of the NO in root cells that induces a negative effect on root growth. A study in arabidopsis indicates that the effect of $\mathrm{NO}$ on root growth is dose-dependent and high NO concentration affects DNA in root cells [83].

\section{Conclusions}

OsHIPP38 showed differential expression in contrasting rice genotypes exposed to salinity. The expression was down and upregulated in susceptible and tolerant genotypes, suggesting the transcriptional response of OsHIPP38 to salt stress. NO pretreatment caused modulation of OsHIPP38, OsGR1, and OsP5CS2 genes in response to salt stress. In the tolerant genotype, OsHIPP3 and OsGR1 expression was lower in NO-pretreated seedlings compared to non-treated ones under saline condition. This may help seedlings in minimizing energy consumption for salt induced transcriptional activities. The NO pretreatment also showed enhancement in dry biomass of rice genotypes exposed to salinity. Leaf senescence was also delayed in NO-pretreated compared to non-treated seedlings under salt condition. However, the effect of $\mathrm{NO}$ on salt stress was more pronounced in the tolerant line compared to the susceptible genotype. Therefore, the use of NO, with the integration of tolerant genes or genotypes, will help in increasing the tolerance level of rice genotypes.

Supplementary Materials: The following are available online at http:/ /www.mdpi.com/2073-4395/8/12/276/s1. Figure S1: Preliminary assessment of rice genotype response to salt stress ( 60 and $120 \mathrm{mmol} / \mathrm{L} \mathrm{NaCl}$ for 12 days). Figure S2: The effect of NO (SNP) on salt tolerance in rice. A- NaCl $100 \mathrm{mmol} / \mathrm{L}, \mathrm{B}-0.1 \mu \mathrm{mol} / \mathrm{L} \mathrm{SNP} \mathrm{and} \mathrm{NaCl}$, C-50 $\mu \mathrm{mol} / \mathrm{L}$ SNP and NaCl, D-100 $\mu \mathrm{mol} / \mathrm{L} \mathrm{SNP}$ and NaCl. SNP and NaCl were applied at the same time and refreshed every three days. The last two genotype in each box are tolerant checks. Figure S3: Optimization of SNP level for salt stress mitigation in rice. Seedlings were treated with SNP for $24 \mathrm{~h}$ and removed and flooded with distilled water. After $24 \mathrm{~h}$, salt stress was applied. A—control, B—salt treated control, C—SNP $0.25 \mathrm{mmol} / \mathrm{L}$ for $24 \mathrm{~h}, \mathrm{D}-\mathrm{SNP} 1 \mathrm{mmol} / \mathrm{L}$.

Author Contributions: Conceptualization, T.A.A.; Methodology, T.A.A. and B.-W.Y.; Software, T.A.A.; Formal analysis, T.A.A.; Investigation, T.A.A. and S.-U.L.; Resources, B.-W.Y.; Writing-original draft preparation, T.A.A.; Writing-review and editing, A.H., and B.-W.Y.; Visualization, B.-W.Y.; Supervision, B.-W.Y.; Project administration, B.-G.M. and B.-W.Y.; Funding acquisition, B.-G.M. and B.-W.Y.

Funding: This research was funded by the Next-Generation BioGreen 21 Program, grant number PJ01367901, Rural Development Administration, Republic of Korea.

Acknowledgments: University of Gondar (Ethiopia) and Korean Government Scholarship Program (KGSP) are acknowledged for their financial support to T.A.A.

Conflicts of Interest: The authors declare no conflicts of interest for this particular research.

\section{References}

1. Gross, B.L.; Zhao, Z.J. Archaeological and genetic insights into the origins of domesticated rice. Proc. Natl. Acad. Sci. USA 2014, 111, 6190-6197. [CrossRef] [PubMed]

2. Idso Craig, D. Estimates of Global Food Production in the Year 2050: Will We Produce Enough to Adequately Feed the World? Center for the Study of Carbon Dioxide and Global Change 2011. Available online: www.Co2science.Org (accessed on 10 June 2018).

3. Ray, D.K.; Mueller, N.D.; West, P.C.; Foley, J.A. Yield trends are insufficient to double global crop production by 2050. PLoS ONE 2013, 8, e66428. [CrossRef] [PubMed]

4. Ray, D.K.; Ramankutty, N.; Mueller, N.D.; West, P.C.; Foley, J.A. Recent patterns of crop yield growth and stagnation. Nat. Commun. 2012, 3, 1293. [CrossRef] [PubMed] 
5. Korres, N.E.; Norsworthy, J.K.; Burgos, N.R.; Oosterhuis, D.M. Temperature and drought impacts on rice production: An agronomic perspective regarding short- and long-term adaptation measures. Water Resour. Rural Dev. 2017, 9, 12-27. [CrossRef]

6. Chakrabortya, S.; Newtonb, A.C. Climate change, plant diseases and food security: An overview. Plant Pathol. 2011, 60, 2-14. [CrossRef]

7. Fahad, S.; Bajwa, A.A.; Nazir, U.; Anjum, S.A.; Farooq, A.; Zohaib, A.; Sadia, S.; Nasim, W.; Adkins, S.; Saud, S.; et al. Crop production under drought and heat stress: Plant responses and management options. Front. Plant Sci. 2017, 8, 1147. [CrossRef] [PubMed]

8. Masutomi, Y.; Takahashi, K.; Harasawa, H.; Matsuoka, Y. Impact assessment of climate change on rice production in asia in comprehensive consideration of process/parameter uncertainty in general circulation models. Agric. Ecosyst. Environ. 2009, 131, 281-291. [CrossRef]

9. Ashikari, M.; Ma, J.F. Exploring the power of plants to overcome environmental stresses. Rice $2015,8$. [CrossRef] [PubMed]

10. Pugh, T.A.M.; Muller, C.; Elliott, J.; Deryng, D.; Folberth, C.; Olin, S.; Schmid, E.; Arneth, A. Climate analogues suggest limited potential for intensification of production on current croplands under climate change. Nat. Commun. 2016, 7, 12608. [CrossRef] [PubMed]

11. Devkota, M.; Martius, C.; Gupta, R.K.; Devkota, K.P.; McDonald, A.J.; Lamers, J.P.A. Managing soil salinity with permanent bed planting in irrigated production systems in central asia. Agric. Ecosyst. Environ. 2015, 202, 90-97. [CrossRef]

12. Lafitte, H.R.; Ismail, A.; Bennett, J. Abiotic stress tolerance in rice for asia-progress and the future. In Proceedings of the 4th International Crop Science Congress, Brisbane, Australia, 26 September-1 October 2004.

13. Qadir, M.; Noble, A.D.; Qureshi, A.S.; Gupta, R.K.; Yuldashev, T.; Karimov, A. Salt-induced land and water degradation in the aral sea basin:A challenge to sustainable agriculture in central asia. Nat. Resour. Forum 2009, 33, 134-149. [CrossRef]

14. Castillo, E.G.; Tuong, T.P.; Ismail, A.; Inubushi, K. Response to salinity in rice: Comparative effects of osmotic and ionic stresses. Plant Prod. Sci. 2015, 10, 159-170. [CrossRef]

15. Moradi, F.; Ismail, A.M. Responses of photosynthesis, chlorophyll fluorescence and ros-scavenging systems to salt stress during seedling and reproductive stages in rice. Ann. Bot. 2007, 99, 1161-1173. [CrossRef] [PubMed]

16. Sharma, P.; Jha, A.B.; Dubey, R.S.; Pessarakli, M. Reactive oxygen species, oxidative damage, and antioxidative defense mechanism in plants under stressful conditions. J. Bot. 2012, 2012, 1-26. [CrossRef]

17. Das, P.; Nutan, K.K.; Singla-Pareek, S.-U.L; Pareek, A. Understanding salinity responses and adopting 'omics-based' approaches to generate salinity tolerant cultivars of rice. Front. Plant Sci. 2015, 6, 712. [CrossRef] [PubMed]

18. Zeng, L.H.; Shannon, M.C. Salinity effects on seedling growth and yield components of rice. Crop Sci. 2000, 40, 996-1003. [CrossRef]

19. Roy, S.J.; Negrao, S.; Tester, M. Salt resistant crop plants. Curr. Opin. Biotechnol. 2014, 26, 115-124. [CrossRef] [PubMed]

20. Munns, R.; Tester, M. Mechanisms of salinity tolerance. Annu. Rev. Plant Biol. 2008, 59, 651-681. [CrossRef] [PubMed]

21. Delauney, A.J.; Verma, D.P.S. Proline biosynthesis and osmoregulation in plants. Plant J. 1993, 4, $215-223$. [CrossRef]

22. Gurmani, A.R.; Bano, A.; Khan, S.U.; Din, J.; Zhang, J.L. Alleviation of salt stress by seed treatment with abscisic acid (aba), 6-benzylaminopurine (ba) and chlormequat chloride (ccc) optimizes ion and organic matter accumulation and increases yield of rice (Oryza sativa L.). Aust. J. Crop. Sci. 2011, 5, 1278-1285.

23. Roy, D.; Bhunia, A.; Basu, N.; Banerjee, S.K. Effect of nacl-salinity on metabolism of proline in salt-sensitive and salt-resistant cultivars of rice. Biol. Plantarum 1992, 34, 159-162. [CrossRef]

24. Verslues, P.E.; Sharma, S. Proline metabolism and its implications for plant-environment interaction. Arabidopsis Book 2010, 8, e0140. [CrossRef] [PubMed]

25. Munns, R. Genes and salt tolerance: Bringing them together. New Phytol. 2005, 167, 645-663. [CrossRef] [PubMed] 
26. Zhu, B.; Su, J.; Chang, M.; Verma, D.P.S.; Fan, Y.-L.; Wu, R. Overexpression of a 81 -pyrroline-5-carboxylate synthetase gene and analysis of tolerance to water-and salt-stress in transgenic rice. Plant Sci. 1998, 139, 41-48. [CrossRef]

27. Hasan, A.; Hafiz, H.R.; Siddiqui, N.; Khatun, M.; Islam, R.; Mamun, A.A. Evaluation of wheat genotypes for salt tolerance based on some physiological traits. J. Crop Sci. Biotechnol. 2016, 18, 333-340. [CrossRef]

28. Hur, J.; Jung, K.H.; Lee, C.H.; An, G.H. Stress-inducible $\mathrm{osp}_{5} \mathrm{Cs}_{2}$ gene is essential for salt and cold tolerance in rice. Plant Sci. 2004, 167, 417-426. [CrossRef]

29. Guo, Z.; Ou, W.; Lu, S.; Zhong, Q. Differential responses of antioxidative system to chilling and drought in four rice cultivars differing in sensitivity. Plant Physiol. Biochem. PPB 2006, 44, 828-836. [CrossRef] [PubMed]

30. Foyer, C.H.; Noctor, G. Redox homeostasis and antioxidant signaling: A metabolic interface between stress perception and physiological responses. Plant Cell 2005, 17, 1866-1875. [CrossRef] [PubMed]

31. Chawla, S.; Jain, S.; Jain, V. Salinity induced oxidative stress and antioxidant system in salt-tolerant and salt-sensitive cultivars of rice (Oryza sativa L.). J. Plant Biochem. Biot. 2013, 22, 27-34. [CrossRef]

32. Mittler, R. Oxidative stress, antioxidants and stress tolerance. Trends Plant Sci. 2002, 7, 405-410. [CrossRef]

33. Foyer, C.H.; Noctor, G. Ascorbate and glutathione: The heart of the redox hub. Plant Physiol. 2011, 155, 2-18. [CrossRef] [PubMed]

34. Hossain, M.; Ismail, M.R.; Uddin, M.K.; Islam, M.Z.; Ashrafuzzaman, M. Efficacy of ascorbate-glutathione cycle for scavenging $\mathrm{h}_{2} \mathrm{O}_{2}$ in two contrasting rice genotypes during salinity stress. Aust. J. Crop Sci. 2013, 7 , 1801-1808.

35. Huang, M.; Guo, Z. Responses of antioxidative system to chilling stress in two rice cultivars differing in sensitivity. Biol. Plantarum 2005, 49, 81-84. [CrossRef]

36. De Abreu-Neto, J.B.; Turchetto-Zolet, A.C.; de Oliveira, L.F.V.; Zanettini, M.H.B.; Margis-Pinheiro, M. Heavy metal-associated isoprenylated plant protein (hipp): Characterization of a family of proteins exclusive to plants. FEBS J. 2013, 280, 1604-1616. [CrossRef] [PubMed]

37. Barth, O.; Vogt, S.; Uhlemann, R.; Zschiesche, W.; Humbeck, K. Stress induced and nuclear localized hipp26 from Arabidopsis thaliana interacts via its heavy metal associated domain with the drought stress related zinc finger transcription factor athb29. Plant Mol. Biol. 2009, 69, 213-226. [CrossRef] [PubMed]

38. Kim, S.M.; Suh, J.P.; Lee, C.K.; Lee, J.H.; Kim, Y.G.; Jena, K.K. Qtl mapping and development of candidate gene-derived DNA markers associated with seedling cold tolerance in rice (Oryza sativa L.). Mol. Genet. Genom. MGG 2014, 289, 333-343. [CrossRef] [PubMed]

39. Fancy, N.N.; Bahlmann, A.K.; Loake, G.J. Nitric oxide function in plant abiotic stress. Plant Cell Environ. 2017, 40, 462-472. [CrossRef] [PubMed]

40. Thomas, D.D.; Miranda, K.M.; Colton, C.A.; Citrin, D.; Espey, M.G.; Wink, D.A. Heme proteins and nitric oxide (no): The neglected, eloquent chemistry in no redox signaling and regulation. Antioxid. Redox Signal. 2003, 5, 307-317. [CrossRef] [PubMed]

41. Misra, A.N.; Misra, M.; Singh, R. Nitric oxide ameliorates stress responses in plants. Plant Soil Environ. 2011, 57, 95-100. [CrossRef]

42. Beligni, M.V.; Lamattina, L. Nitric oxide interferes with plant photo-oxidative stress by detoxifying reactive oxygen species. Plant Cell Environ. 2002, 25, 737-748. [CrossRef]

43. Hsu, Y.T.; Kao, C.H. Cadmium toxicity is reduced by nitric oxide in rice leaves. Plant Growth Regul. 2004, 42, 227-238. [CrossRef]

44. Kausar, F.; Shahbaz, M.; Ashraf, M. Protective role of foliar-applied nitric oxide in triticum aestivum under saline stress. Turk. J. Bot 2013, 37, 1155-1165. [CrossRef]

45. Farooq, M.; Basra, S.M.A.; Wahid, A.; Rehman, H. Exogenously applied nitric oxide enhances the drought tolerance in fine grain aromatic rice (Oryza sativa L.). J. Agron. Crop. Sci. 2009, 195, 254-261. [CrossRef]

46. Ahmad, P.; Latef, A.A.A.; Hashem, A.; Abd Allah, E.F.; Gucel, S.; Tran, L.S.P. Nitric oxide mitigates salt stress by regulating levels of osmolytes and antioxidant enzymes in chickpea. Front. Plant Sci 2016, 7, 347. [CrossRef] [PubMed]

47. Egbichi, I.; Keyster, M.; Ludidi, N. Effect of exogenous application of nitric oxide on salt stress responses of soybean. S. Afr. J. Bot. 2014, 90, 131-136. [CrossRef]

48. Singh, H.P.; Batish, D.R.; Kaur, G.; Arora, K.; Kohli, R.K. Nitric oxide (as sodium nitroprusside) supplementation ameliorates cd toxicity in hydroponically grown wheat roots. Environ. Exp. Bot. 2008, 63, 158-167. [CrossRef] 
49. Esim, N.; Atici, O.; Mutlu, S. Effects of exogenous nitric oxide in wheat seedlings under chilling stress. Toxicol. Ind. Health 2014, 30, 268-274. [CrossRef] [PubMed]

50. Liu, X.W.; Wang, L.; Liu, L.Y.; Guo, Y.D.; Ren, H.Z. Alleviating effect of exogenous nitric oxide in cucumber seedling against chilling stress. Afr. J. Biotechnol. 2011, 10, 4380-4386.

51. Ahmad, P.; Ahanger, M.A.; Alyemeni, M.N.; Wijaya, L.; Alam, P. Exogenous application of nitric oxide modulates osmolyte metabolism, antioxidants, enzymes of ascorbate-glutathione cycle and promotes growth under cadmium stress in tomato. Protoplasma 2018, 255, 79-93. [CrossRef] [PubMed]

52. Lopez-Carrion, A.I.; Castellano, R.; Rosales, M.A.; Ruiz, J.M.; Romero, L. Role of nitric oxide under saline stress: Implications on proline metabolism. Biol. Plantarum 2008, 52, 587-591. [CrossRef]

53. Ruan, H.H.; Shen, W.B.; Xu, L.L. Nitric oxide involved in the abscisic acid induced proline accumulation in wheat seedling leaves under salt stress. Acta Bot. Sin. 2004, 46, 1307-1315.

54. Fan, H.F.; Du, C.X.; Guo, S.R. Effect of nitric oxide on proline metabolism in cucumber seedlings under salinity stress. J. Am. Soc. Hortic. Sci. 2012, 137, 127-133.

55. Glenn, B.G.; Senadhira, D. Genetic-analysis of salinity tolerance in rice (Oryza-sativa L.). Theor. Appl. Gen. 1993, 86, 333-338.

56. Bradford, M.M. A rapid and sensitive method for the quantitation of microgram quantities of protein utilizing the principle of protein-dye binding. Anal. Biochem. 1976, 72, 248-254. [CrossRef]

57. Aebi, H. Catalase in vitro. In Methods in Enzymology; Packer, L., Ed.; Academic Press: San Diego, CA, USA, 1984; Volume 105, pp. 121-126.

58. Imran, Q.M.; Falak, N.; Hussain, A.; Mun, B.G.; Sharma, A.; Lee, S.U.; Kim, K.M.; Yun, B.W. Nitric oxide responsive heavy metal-associated gene athmad1 contributes to development and disease resistance in arabidopsis thaliana. Front. Plant Sci. 2016, 7, 1712. [CrossRef] [PubMed]

59. Ambawat, S.; Sharma, P.; Yadav, N.R.; Yadav, R.C. Myb transcription factor genes as regulators for plant responses: An overview. Physiol. Mol. Biol. Plants 2013, 19, 307-321. [CrossRef] [PubMed]

60. Sarkar, N.K.; Thapar, U.; Kundnani, P.; Panwar, P.; Grover, A. Functional relevance of j-protein family of rice (Oryza sativa). Cell. Stress Chaperon 2013, 18, 321-331. [CrossRef] [PubMed]

61. Mun, B.-G.; Lee, S.-U.; Hussain, A.; Kim, H.-H.; Rolly, N.K.; Jung, K.-H.; Yun, B.-W. S-nitrosocysteineresponsive genes modulate diverse regulatory pathways in Oryza sativa: A transcriptome profiling study. Funct. Plant Biol. 2018, 45, 630-644. [CrossRef]

62. Fatma, M.; Masood, A.; Per, T.S.; Khan, N.A. Nitric oxide alleviates salt stress inhibited photosynthetic performance by interacting with sulfur assimilation in mustard. Front. Plant Sci. 2016, 7, 521. [CrossRef] [PubMed]

63. Begara-Morales, J.C.; Sanchez-Calvo, B.; Chaki, M.; Valderrama, R.; Mata-Perez, C.; Padilla, M.N.; Corpas, F.J.; Barroso, J.B. Antioxidant systems are regulated by nitric oxide-mediated post-translational modifications (no-ptms). Front. Plant Sci. 2016, 7, 152. [CrossRef] [PubMed]

64. Yoshiba, Y.; Kiyosue, T.; Nakashima, K.; YamaguchiShinozaki, K.; Shinozaki, K. Regulation of levels of proline as an osmolyte in plants under water stress. Plant Cell Physiol. 1997, 38, 1095-1102. [CrossRef] [PubMed]

65. Mostofa, M.G.; Seraj, Z.I.; Fujita, M. Interactive effects of nitric oxide and glutathione in mitigating copper toxicity of rice (Oryza sativa L.) seedlings. Plant Signal. Behav. 2015, 10, e991570. [CrossRef] [PubMed]

66. Panda, P.; Nath, S.; Chanu, T.T.; Sharma, G.D.; Panda, S.K. Cadmium stress-induced oxidative stress and role of nitric oxide in rice (Oryza sativa L.). Acta Physiol. Plant 2011, 33, 1737-1747. [CrossRef]

67. Baena-Gonzalez, E. Energy signaling in the regulation of gene expression during stress. Mol. Plant 2010, 3, 300-313. [CrossRef] [PubMed]

68. Chutipaijit, S.; Cha-um, S.; Sompornpailin, K. High contents of proline and anthocyanin increase protective response to salinity in Oryza sativa L. Spp. Indica. Aust. J. Crop. Sci. 2011, 5, 1191-1198.

69. Kibria, M.G.; Hossain, M.; Murata, Y.; Hoque, M.A. Antioxidant defense mechanisms of salinity tolerance in rice genotypes. Rice Sci. 2017, 24, 155-162. [CrossRef]

70. Pal, M.; Singh, D.K.; Rao, L.S.; Singh, K.P. Photosynthetic characteristics and activity of antioxidant enzymes in salinity tolerant and sensitive rice cultivars. Indian J. Plant Physiol. 2004, 9, 407-412.

71. Garg, N.; Kaur, H. Response of antioxidant enzymes, phytochelatins and glutathione production towards cd and zn stresses in Cajanus cajan (L.) millsp genotypes colonized by arbuscular mycorrhizal fungi. J. Agron. Crop. Sci. 2013, 199, 118-133. [CrossRef] 
72. Passardi, F.; Cosio, C.; Penel, C.; Dunand, C. Peroxidases have more functions than a swiss army knife. Plant Cell Rep. 2005, 24, 255-265. [CrossRef] [PubMed]

73. Almagro, L.; Ros, L.V.G.; Belchi-Navarro, S.; Bru, R.; Barcelo, A.R.; Pedreno, M.A. Class iii peroxidases in plant defence reactions. J. Exp. Bot. 2009, 60, 377-390. [CrossRef] [PubMed]

74. Pattanagul, W.; Thitisaksakul, M. Effect of salinity stress on growth and carbohydrate metabolism in three rice (Oryza sativa L.) cultivars differing in salinity tolerance. Indian J. Exp. Biol. 2008, 46, 736-742. [PubMed]

75. Sudhir, P.; Murthy, S.D.S. Effects of salt stress on basic processes of photosynthesis. Photosynthetica 2004, 42, 481-486. [CrossRef]

76. Tiwari, B.S.; Bose, A.; Ghosh, B. Photosynthesis in rice under a salt stress. Photosynthetica 1997, 34, $303-306$. [CrossRef]

77. Oukarroum, A.; Bussotti, F.; Goltsev, V.; Kalaji, H.M. Correlation between reactive oxygen species production and photochemistry of photosystems i and ii in Lemna gibba L. Plants under salt stress. Environ. Exp. Bot. 2015, 109, 80-88. [CrossRef]

78. Miller, G.; Suzuki, N.; Ciftci-Yilmaz, S.; Mittler, R. Reactive oxygen species homeostasis and signalling during drought and salinity stresses. Plant Cell Environ. 2010, 33, 453-467. [CrossRef] [PubMed]

79. Mitsuya, S.; Kawasaki, M.; Taniguchi, M.; Miyake, H. Light dependency of salinity-induced chloroplast degradation. Plant Prod. Sci. 2003, 6, 219-223. [CrossRef]

80. Wei, L.L.; Derrien, B.; Gautier, A.; Houille-Vernes, L.; Boulouis, A.; St-Marcoux, D.; Malnoe, A.; Rappaport, F.; de Vitry, C.; Vallon, O.; et al. Nitric oxide-triggered remodeling of chloroplast bioenergetics and thylakoid proteins upon nitrogen starvation in Chlamydomonas reinhardtii. Plant Cell 2014, 26, 353-372. [CrossRef] [PubMed]

81. Balotf, S.; Islam, S.; Kavoosi, G.; Kholdebarin, B.; Juhasz, A.; Ma, W.J. How exogenous nitric oxide regulates nitrogen assimilation in wheat seedlings under different nitrogen sources and levels. PLoS ONE 2018, 13, e0190269. [CrossRef] [PubMed]

82. Yu, M.D.; Lamattina, L.; Spoel, S.H.; Loake, G.J. Nitric oxide function in plant biology: A redox cue in deconvolution. New Phytol. 2014, 202, 1142-1156. [CrossRef] [PubMed]

83. Bai, S.L.; Li, M.M.; Yao, T.; Wang, H.; Zhang, Y.C.; Xiao, L.H.; Wang, J.Z.; Zhang, Z.; Hu, Y.; Liu, W.Z.; et al. Nitric oxide restrains root growth by DNA damage induced cell cycle arrest in Arabidopsis thaliana. Nitric Oxide 2012, 26, 54-60. [CrossRef] [PubMed] 